\title{
The identification of the mechanism of electrocatalytic ozone generation on $\mathrm{Ni} / \mathrm{Sb}-\mathrm{SnO} \mathrm{O}_{2}$
}

\author{
P. A. Christensen ${ }^{1}$, P. S. Attidekou ${ }^{1}$, R. G. Egdell ${ }^{2}$, S. Maneelok ${ }^{1}$, D. A. C. Manning ${ }^{3}$ and R. \\ Palgrave ${ }^{4}$.
}

1 School of Chemical and Process Engineering, Bedson Building, Newcastle University, Newcastle upon Tyne, NE1 7RU.

2. Department of Chemistry, University of Oxford, Inorganic Chemistry Laboratory, South Parks Road, Oxford OX1 3QR.

3. School of Civil Engineering and Geosciences, Drummond Building, Newcastle University, Newcastle upon Tyne, NE1 7RU.

4. Department of Chemistry, Christopher Ingold Building, UCL, London, WC1H 0AJ.

\begin{abstract}
This paper reports a systematic study of the co-doping of $\mathrm{SnO}_{2}$ with $\mathrm{Sb}$ and $\mathrm{Ni}$ in order to identify the mechanism responsible for the electrocatalytic generation of ozone on $\mathrm{Ni} / \mathrm{Sb}-\mathrm{SnO}_{2}$. Based on interpretation of a combination of X-ray diffraction, BET surface area measurements $\left(\mathrm{N}_{2}\right)$ and thermal analysis, the formation of ozone appears to take place on particle surfaces of composite Sb$\mathrm{SnO}_{2}$ grains, and is controlled by diffusion of $\mathrm{OH}$ along internal crystallite surfaces within the grain. $\mathrm{Sb}$-doped $\mathrm{SnO}_{2}$ is inactive with respect to ozone evolution in the absence of $\mathrm{Ni}$, demonstrating a synergic interaction between nickel and antimony. From XPS investigations, $\mathrm{Sb}(\mathrm{V})$ ions substitute for $\mathrm{Sn}(\mathrm{IV})$ in the lattice, with a preference for centrosymmetric coordination sites whilst the $\mathrm{Sb}$ (III) ions occur at grain surfaces or boundaries. Ni was not detected by XPS being located in the subsurface region at concentrations below the detection limit of the instrument. In addition to identifying a possible mechanism for ozone formation, the study resulted in the production of active nanopowders which will allow the fabrication of high surface-area anodes with the potential to exceed the space-time yields of $\beta-\mathrm{PbO}_{2}$ anodes, permitting the application the $\mathrm{Ni} / \mathrm{Sb}-\mathrm{SnO}_{2}$ anodes in the treatment of real waters.
\end{abstract}

\section{Introduction}

Ozone is generally regarded as an environmentally friendly oxidant that has been employed in water treatment since the start of the $20^{\text {th }}$ century. ${ }^{1}$ In recent years, the areas of application of ozone have increased significantly to include domestic goods such as washing machines and icemakers, and to the chemical-free cleaning and sterilization of surfaces in hospitals and fertility clinics. With respect to the latter, there is increasing evidence that the volatile organic compounds released by conventional cleaning agents can be harmful to embryos and have a detrimental effect upon pregnancy rates. $^{2}$ The most common method of generating ozone, particularly in industrial quantities, is using cold corona discharge (CCD), first reported by Siemens in 1857. ${ }^{3}$ However, such methods have a number of disadvantages including: (i) low concentration of $\mathrm{O}_{3}$ in the output, in the range of $2 \%$ to $12 \%$ by volume ${ }^{4}$, (ii) CCD generators require cold, dry and pure $\mathrm{O}_{2}$ (if air is employed the $\mathrm{O}_{3}$ concentration and production efficiency are significantly reduced and nitrous oxides are produced ${ }^{5}$ ), (iii) $\mathrm{CCD}$ generates only gas phase $\mathrm{O}_{3}$, which is difficult to dissolve for aqueous applications ${ }^{5}$ and (iv) $\mathrm{CCD}$ requires high voltage ( $\mathrm{kV}$ range) power supplies.

In contrast, the electrochemical generation of ozone offers a number of advantages that include: the possibility of generating high concentrations of ozone in the gas and liquid phases, no need for gas feeds of any description, and robust, proven cell and system technology through the established chlor-alkali industry. ${ }^{4}$ The major challenges to the general application of electrochemical ozone generation, and the reasons why the technology is yet to see major commercial application, are: (1) low ozone current efficiencies and/or current densities and (2) the poisoning of cationic polymer 
electrolyte membranes (PEMs) by common ions found in real water, especially $\mathrm{Na}^{+}, \mathrm{Ca}^{2+}$ and $\mathrm{Mg}^{2+}$; PEM operation is essential if the water to be treated is not to have significant quantities of ions added to render it ionically conducting. $\beta-\mathrm{PbO}_{2}$ is the most common anode employed to generate ozone and, whilst particulate electrodes of this type can be employed to generate current densities of ca. $1.0-1.5 \mathrm{~A} \mathrm{~cm}^{-2}$, they do so with current efficiencies only up to ca. $10 \% .^{6}$ There are two materials capable of current efficiencies of $\geq 20 \%$ : boron doped diamond (BDD) and Ni and Sb-codoped $\mathrm{SnO}_{2}{ }^{4}$

BDD anodes have been employed to generate $\mathrm{O}_{3}$ in PEM-based, electrolyte-free water at current efficiencies up to $47 \%$ and current densities up to $530 \mathrm{~mA} \mathrm{~cm}^{-2} \cdot{ }^{7-9}$ However, the cell voltages required with such systems are high, and it is not at all clear that BDD anodes can be expected to produce ozone routinely as they are more usually associated with the direct oxidation of organics.

The first report of the oxidation of water to ozone using an electrode comprising a ceramic Ni/Sb$\mathrm{SnO}_{2}$ coating on a Ti substrate in aqueous acidic electrolyte was by Cheng and Chan in 2004: initially, the authors were unaware of Ni contamination and reported the ozone activity of Sb$\mathrm{SnO}_{2}{ }^{10}$ : this was corrected in a later paper ${ }^{11}$ where a current efficiency up to $36 \%$ was reported, albeit at a low current densities (typically $<40 \mathrm{~mA} \mathrm{~cm}^{-2}$ ). Later, Christensen et al. ${ }^{12-13}$ achieved current efficiencies up to $50 \%$ at current densities up to $100 \mathrm{~mA} \mathrm{~cm}^{-2}$. Chan has reported the operation of $\mathrm{Ni} / \mathrm{Sb}-\mathrm{SnO}_{2}$ anodes in electrolyte-free water. ${ }^{14-15}$ Thus, $\mathrm{Ni} / \mathrm{Sb}-\mathrm{SnO}_{2}$ anodes are capable of operating with high current efficiencies, but, to date, the yields of ozone have been low as it has not yet proven possible to produce $\mathrm{Ni} / \mathrm{Sb}-\mathrm{SnO}_{2}$ as high surface area powders, unlike $\beta-\mathrm{PbO}_{2}$ anodes, If it were possible incorporate high area powder into working electrodes, not only would such anodes be able to exceed $\beta-\mathrm{PbO}_{2}$ anodes in space-time yield ${ }^{6}$, but the poisoning of PEMs such as Nafion when using real waters could be avoided due to the high proton fluxes through the membranes competing efficiently with $\mathrm{Na}^{+}$etc.

We have recently obtained lifetimes of up to 600 hours when using $\mathrm{Ni} / \mathrm{Sb}-\mathrm{SnO}_{2}$ anodes to electrolyse acid electrolyte with constant current efficiencies and current densities. ${ }^{13,16}$ This strongly suggests that the Ni responsible for the ozone activity is not exposed to electrolyte as it would be expected to dissolve under such acidic and highly oxidising conditions. This also highlights another problem with this material: despite its discovery over 10 years ago, the mechanism of ozone generation at $\mathrm{Ni} / \mathrm{Sb}-\mathrm{SnO}_{2}$ remains unclear. Various authors have speculated on this issue. ${ }^{17-19}$ For example, the involvement of $\mathrm{Ni}$ (III) has been suggested, but this speculation is not based on specific evidence.

The fact that the addition of very small amounts of $\mathrm{Ni}$ to $\mathrm{Sb}$-doped $\mathrm{SnO}_{2}$ changes the material from being inactive to the electrochemical production of ozone to a highly active and highly selective ozone anode is remarkable, and could not have been predicted. However, the mechanism by which $\mathrm{O}_{3}$ evolution takes place at $\mathrm{Ni} / \mathrm{Sb}-\mathrm{SnO}_{2}$ anodes remains obscure, primarily as a result of the lack of quantitative experimental data. Until there is definitive and quantitative analytical evidence on the composition of $\mathrm{Ni} / \mathrm{Sb}-\mathrm{SnO}_{2}$ anodes to allow structure/activity correlations to be made, attempts to understand the mechanism of ozone generation at these materials will remain speculative.

The aim of the work described in this paper was to elucidate the nature of the active site for ozone generation at $\mathrm{Ni} / \mathrm{Sb}-\mathrm{SnO}_{2}$ anodes. In order to achieve this, it was decided to synthesize $\mathrm{Ni} / \mathrm{Sb}-\mathrm{SnO}_{2}$ powders using the same precursor solutions employed previously to make the ceramic anodes ${ }^{12-20}$ and to adopt a step-by-step approach by carrying out full characterization of these using surface 
area determination by gas adsorption, powder X-ray diffraction (XRD) and thermogravimetric analysis coupled with evolved gas analysis by mass spectrometry (TGA) to investigate the structural and other changes induced by doping $\mathrm{SnO}_{2}$ first with $\mathrm{Sb}$ then with varying amounts of nickel, and to correlate the latter with ozone activity and selectivity. The preliminary study on $\mathrm{SnO}_{2}$ has been reported in a previous paper. ${ }^{21}$ As well as identifying the active site for $\mathrm{O}_{3}$, it is believed that producing active, high surface area $\mathrm{Ni} / \mathrm{Sb}-\mathrm{SnO}_{2}$ nanopowders will allow electrochemical cells to be produced capable of high current densities, and hence remove the problem of the cation fouling of PEMs. Importantly, interpretation of the experimental results recognises that crystallinity determined by XRD and particle size calculated from BET data give different information about the material, a fact usually overlooked in other reports.

\section{Experimental}

The $\mathrm{SnO}_{2}$ nanopowders were prepared via a hydrothermal route using a method adapted from that of Fujihara and co-workers ${ }^{22}$, as shown in Scheme 1. ${ }^{21}$ The $\mathrm{SnCl}_{4} .5 \mathrm{H}_{2} \mathrm{O}$ (98\%, Sigma-Aldrich), $\mathrm{SbCl}_{3}$ (99\%, Sigma-Aldrich) and $\mathrm{NiCl}_{2} \cdot 6 \mathrm{H}_{2} \mathrm{O}$ (99\%, Sigma-Aldrich) were used as received. Deionised (DI) water was obtained from a Millipore Milli-Q system, $18 \mathrm{M} \Omega \mathrm{cm}$. Two methods were employed to produce $\mathrm{Ni}$ co-doped $\mathrm{Sb}-\mathrm{SnO}_{2}$ : the first involved mixing all the precursor solutions together prior to refluxing, as in Scheme 1. The Ni content of these samples is referred below in terms of the wt.\% in the precursor solutions. The second method involved the production of Sb$\mathrm{SnO}_{2}$ nanopowders calcined at temperature $\mathrm{T}_{1}$, which were then doped with $\mathrm{Ni}$ by forming a slurry of the appropriate wt.\% in $\mathrm{NiCl}_{2}$ solution and calcining at temperature $\mathrm{T}_{2}$, as shown in Scheme 2. The two forms of $\mathrm{Ni}$ and $\mathrm{Sb}$-doped $\mathrm{SnO}_{2}$ are referred to as " $\mathrm{x} \% \mathrm{Ni} / \mathrm{Sb}-\mathrm{SnO}_{2} \mathrm{~T}$ " and " $\mathrm{T}_{1} \mathrm{Sb}$ $\mathrm{SnO}_{2} / \mathrm{x} \% \mathrm{Ni} \mathrm{T}_{2}$, respectively.

Ti foil substrates of dimensions $0.8 \mathrm{~cm} \times 0.8 \mathrm{~cm}$ were pressed in a Chauffante Elcometer press at room temperature and $1000 \mathrm{~N}$ for 5 minutes to flatten them. $0.5 \mathrm{~mm}$ diameter Ti wires were cut to ca. $10 \mathrm{~cm}$, one end hammered flat and then spot-welded to the titanium foil along the middle of Ti foil or mesh to the edge in order to ensure contact with the entire length of the substrate. The mesh or foil substrates were degreased by immersion in a beaker containing acetone, followed by thorough washing with DI water; this procedure was repeated twice. The Ti substrates were then etched by boiling in $10 \mathrm{wt} . \%$ oxalic acid $\left(10 \mathrm{~g}\right.$ in $100 \mathrm{~cm}^{3}$ DI water) for at least 30 minutes until the solution changed to a brownish tinge. The solution was allowed to cool to room temperature after which the substrates were washed with DI water. They were then placed in fresh DI water in a beaker and sonicated for 15 minutes per time, repeating the procedure twice with fresh water until no grease was observed on the surface of the water. The meshes or foils were then dried in air for 1 hour by placing in a beaker with the substrates uppermost. Each Ti substrate was weighed and the mass recorded.

$100 \mathrm{mg}$ of the nanocrystalline powder was mixed with $10 \mathrm{~cm}^{3}$ of ethanol solution. The powder + ethanol was stirred for ca. 4 hours until a homogeneous slurry was obtained. $0.1 \mathrm{~cm}^{3}$ of the slurry was coated on the Ti foil and was allowed to dry in air. The electrodes were then placed in an oven at $110{ }^{\circ} \mathrm{C}$ for $5 \mathrm{~min}$, removed and calcined at 460 or $700^{\circ} \mathrm{C}$ for 1 hour in a Carbolite $12 \mathrm{~F} 12 / 25 / 700$ furnace.

Powder diffraction patterns were measured on a PANalytical X'Pert Pro MPD diffractometer, powered by a Philips PW3040/60 X-ray generator operated at $40 \mathrm{kV}$ with $40 \mathrm{~mA}$ emission current and incorporating an $\mathrm{X}^{\prime}$ Celerator detector, using $\mathrm{Cu} \mathrm{K \alpha}$ radiation $(\lambda=1.54180 \AA)$ ). Diffraction peaks were acquired between $2 \theta=10$ to $60^{\circ}$ and were assigned using the ICSD crystallographic data base. 
The peaks at $2 \theta=26.43^{\circ}, 33.58^{\circ}$ and $51.49^{\circ}$ were employed to determine effective crystallite size via the Scherrer equation.

X-ray photoelectron spectroscopy (XPS) was carried out using a Thermo K-alpha spectrometer. The instrument used a $72 \mathrm{~W}$ monochromated $\mathrm{Al} \mathrm{K \alpha}$ X-ray source (photon energy of $1486.6 \mathrm{eV}$ ) and a dual beam flood gun, using both electrons and argon cations to compensate for sample charging. The X-rays were microfocused at source to give a spot size on the sample of $400 \mu \mathrm{m}$. The analysis chamber had a base pressure of $10^{-9}$ mbar. Photoelectrons were measured using a $125 \mathrm{~mm}$ radius concentric hemispherical analyser and spectra were recorded in constant analyser energy mode. Pass energies of $50 \mathrm{eV}$ and a binding energy step size of $0.1 \mathrm{eV}$ were used to record high resolution spectra, whilst pass energy of $200 \mathrm{eV}$ and a binding energy step size of $1.0 \mathrm{eV}$ were used to record survey spectra. Photoelectrons were detected using a 128 channel position sensitive detector. The binding energy scale of the spectrometer is regularly calibrated using a three point calibration ( $\mathrm{Au}$, $\mathrm{Ag}$ and $\mathrm{Cu}$ ).

TGA analyses were carried out in an atmosphere of flowing $\left(40 \mathrm{~cm}^{3} \mathrm{~min}^{-1}\right)$ air, in a Netzsch STA 449C TG-DSC (thermogravimetry-differential scanning calorimetry, or TG-DSC) system, connected to a Netzsch Aeolos 403C quadrupole mass spectrometer (QMS; m/z range 10-300). Samples were loaded into alumina crucibles (approximately 30-40 mg sample mass). A heating rate of $5{ }^{\circ} \mathrm{C} \mathrm{min}-1$ was used from $25^{\circ} \mathrm{C}-900{ }^{\circ} \mathrm{C}$, held at $900{ }^{\circ} \mathrm{C}$ for 10 minutes then cooled at $5{ }^{\circ} \mathrm{C}$ $\mathrm{min}^{-1}$ to room temperature. The only evolved species detected on heating the samples was water.

The surface areas of the $\mathrm{SnO}_{2}$ powders were determined with a Thermo Scientific Surfer analyser using multipoint Brunauer Emmett and Teller (BET) adsorption isotherms. The sample of mass 75 mg was prepared by degassing at $250{ }^{\circ} \mathrm{C}$ for 3 hours with a ramp rate of $5{ }^{\circ} \mathrm{C} \mathrm{min}^{-1}$ to reach this temperature prior to $\mathrm{N}_{2}$ adsorption.

The electrochemical cell employed in this work was a $1 \mathrm{~cm}$ pathlength quartz cuvette. ${ }^{10-11,20} 3 \mathrm{~cm}^{3}$ $0.5 \mathrm{M} \mathrm{H}_{2} \mathrm{SO}_{4}$ was employed as electrolyte. A $0.64 \mathrm{~cm}^{2} \mathrm{Pt}$-Ti mesh cathode was held vertically against one of the opaque sides of the cuvette. The anode was held flat on the bottom of the cuvette which was sealed with a PTFE cover and placed in the cuvette holder in Shimadzu 1240 mini spectro-photometer. The anode was connected to the (+) terminal of a Thandar - TS30228 power supply and the cathode to the (-) terminal. A reference spectrum was collected at open circuit after which the potential was stepped to the working value (typically $2.7 \mathrm{~V}$ ) for $30 \mathrm{~s}$, after which the cell was switched to open circuit and further spectra collected for 300s (to avoid interference from gas bubbles). The steady state absorbance at $258 \mathrm{~nm}$ was used to calculate the ozone current efficiency, assuming an extinction coefficient of $3000 \mathrm{M}^{-1} \mathrm{~cm}^{-1}{ }^{20}$

\section{Results and discussion}

Figures S1(a) - (c) show typical photographs of the powders prepared by the hydrothermal method. In general, both the uncalcined $\mathrm{Sb}-\mathrm{SnO}_{2}$ and $\mathrm{Ni} / \mathrm{Sb}-\mathrm{SnO}_{2}$ powders and the samples calcined at $300{ }^{\circ} \mathrm{C}$ were yellowish-white; those calcined at $400{ }^{\circ} \mathrm{C}$ were grey; and the samples calcined at $700{ }^{\circ} \mathrm{C}$ were blue. The blue colouration is directly linked to activation of the $\mathrm{Sb}(\mathrm{V})$ dopant, which when incorporated into bulk Sn sites acts as a one electron donor. Carrier densities in the range around $10^{20} \mathrm{~cm}^{-3}$ give rise to a plasmon in the near infrared region, typically around $0.5 \mathrm{eV}$. The reflectivity drops from a high value below this energy to a very low value just above the plasmon energy. The reflectivity then recovers across the visible region and is higher at the blue end of the spectrum than at the red end. The blue colour produced in this way is similar to that found for sodium tungsten bronzes $\mathrm{Na}_{x} \mathrm{WO}_{3}$ at low sodium doping levels. ${ }^{23} \mathrm{Sb}$ (III) cannot be easily 
accommodated in bulk sites as it has a propensity to occupy only sites lacking inversion symmetry It can however occupy sites at free surfaces or grain boundary interfaces.

\section{$\mathrm{The} \mathrm{SnO}_{2}, \mathrm{Sb}-\mathrm{SnO}_{2}$ and $\mathrm{Ni} / \mathrm{Sb}-\mathrm{SnO}_{2}$ samples \\ $X R D$}

Typical X-ray diffraction patterns for the $\mathrm{SnO}_{2}$ samples are shown in Figure S2. The XRD patterns showed all the samples to be tetragonal cassiterite which has the rutile structure (Cassiterite, syn; Q: $\mathrm{S}$; 00-041-1445). No other phases were observed suggesting that the Sb ions replace $\mathrm{Sn}(\mathrm{IV})$ in the lattice, in agreement with the literature, where such replacement is observed even at high doping levels. ${ }^{24-25}$

Table ST1 summarises the XRD data. As can be seen from the table, addition of Sb results in a reduction in crystallite size and so inhibits crystal growth, in agreement with the work of Rockenberger et al. ${ }^{25}$, whilst calcining, as would be expected, improves crystallinity and increases the crystallite size. Thus, as-prepared $\mathrm{SnO}_{2}$ showed a crystallite size of $11 \mathrm{~nm}$ increasing to $22 \mathrm{~nm}$ after calcining at $700{ }^{\circ} \mathrm{C}$, whilst the as-prepared $\mathrm{Sb}-\mathrm{SnO}_{2}$ crystals had an equivalent crystallite size of ca. $4.3 \mathrm{~nm}$, which did not increase appreciably on calcining at 300 or $400{ }^{\circ} \mathrm{C}$, but increased to 9.5 $\mathrm{nm}$ after calcining at $700{ }^{\circ} \mathrm{C}$.

From Table ST1 it is clear that calcination temperature, Sb content and Ni content had little or no effect upon the unit cell dimensions. This is to be expected on the basis of Végards law in view of of the low doping levels involved and the similarity of ionic sizes for $\mathrm{Sn}(\mathrm{IV}), \mathrm{Ni}(\mathrm{II})$ and $\mathrm{Sb}(\mathrm{V})$.

\section{$B E T$}

Table ST2 shows the BET surface areas and the surface areas calculated from the crystallite sizes obtained from the XRD line broadening, assuming spherical crystallites for simplicity. Figure 1 shows plots of the ratio of the grain volumes calculated from the BET data and the crystallite volumes calculated from the XRD data. This is justified as cassiterite commonly has a bipyramidal habit, which is roughly equidimensional. As may be seen from Figure 1, the addition of $\mathrm{Sb}$ to $\mathrm{SnO}_{2}$ causes a significant increase in the number of crystallites per particle. The first addition of Ni also has a significant effect, but results in a decrease in the number of crystallites per particle (the magnitude of this decrease being less than the initial increase observed on the addition of $\mathrm{Sb}$ ), whilst further addition of Ni has little or no effect. These data suggest that both Sb and Ni occupy sites at or near grain boundary interfaces and are thus able to influence the agglomeration of crystallites. It is generally accepted in the literature (see below) that the doping of $\mathrm{SnO}_{2}$ by $\mathrm{Sb}$ results in $\mathrm{Sb}(\mathrm{V})$ ions on bulk $\mathrm{Sn}(\mathrm{IV})$ lattice sites with $\mathrm{Sb}(\mathrm{III})$ ions confined to surface grain boundary interfaces. ${ }^{24,26-33}$

\section{$X P S$}

Widescan XPS showed core lines due to $\mathrm{Sn}, \mathrm{Sb}, \mathrm{O}$ and adventitious $\mathrm{C}$ contamination. There was pronounced Sb segregation, as is evident in Figure S3 which is typical of the XPS spectra obtained using the various Sb-containing samples. As can be seen from the spectrum, the ratio of the intensities of the $S b 3 d_{3 / 2}$ to $S n 3 d_{3 / 2}$ peaks (after correction for sensitivity factors) is 0.14 compared with a nominal bulk doping ratio of 0.06 . Moreover the $\mathrm{Sb} 3 \mathrm{~d}_{3 / 2}$ peak showed pronounced asymmetry and was fitted to two components at $540.6 \mathrm{eV}$ and $541.5 \mathrm{eV}$ associated with $\mathrm{Sb}(\mathrm{III})$ and $\mathrm{Sb}(\mathrm{V})$, respectively.

It was not possible to detect $\mathrm{Ni}$ in the $\mathrm{Ni} / \mathrm{Sb}-\mathrm{SnO}_{2}$ nanopowder samples presumably because the concentration of $\mathrm{Ni}$ in the sampling depth, of ca. $10 \mathrm{~nm}$, was less than the detection limit, the upper 
bound of which was estimated to be about 0.02 at.\%. The technique is not capable of probing the internal crystallite surfaces within the grains. Table ST3 summarizes the XPS data obtained using the various nanopowders including the total $\mathrm{Sb}$ content and the concentrations $\mathrm{Sb}(\mathrm{III})$ and $\mathrm{Sb}(\mathrm{V})$.

As can be seen from Table ST3, there was little or no variation in the total Sb content between the $\mathrm{Sb}-\mathrm{SnO}_{2}$ and the $\mathrm{Ni} / \mathrm{Sb}-\mathrm{SnO}_{2}$ samples, ruling out a role for $\mathrm{Sb}$ in explaining the data shown in Figure 1. Further, as would be expected, the Ni content also did not appear to influence the incorporation of $\mathrm{Sb}$. However, it is clear from the table that the calcination temperature had a significant effect on the concentration of $\mathrm{Sb}$, and that this was due to $\mathrm{Sb}$ (III) enrichment, in agreement with the literature, where it is generally accepted that ${ }^{24,26-33}$ : (i) Sb ions replace $\mathrm{Sn}$ ions in the cassiterite lattice without strong modification of the lattice; (ii) both $\mathrm{Sb}$ (III) and $\mathrm{Sb}(\mathrm{V}$ ) ions are produced following calcining, irrespective of whether $\mathrm{SbCl}_{3}$ or $\mathrm{SbCl}_{5}$ is employed as the precursor; (iii) $\mathrm{Sb}(\mathrm{V})$ ions are accommodated in the bulk of the lattice due to their similar size to $\mathrm{Sn}(\mathrm{IV})$ (ionic radius $=0.60 \AA$, cf. $0.69 \AA$ for $\mathrm{Sn}(\mathrm{IV})$ ) and preference for centrosymmetric coordination sites whilst the $\mathrm{Sb}$ (III) ions $(0.76 \AA)$ are accommodated at the surface or at grain boundaries. It has been suggested ${ }^{27,33}$ that the $\mathrm{Sb}(\mathrm{III})$ ions replace the topmost layer of $\mathrm{Sn}(\mathrm{IV})$ ions, with essentially the bulk composition of $\mathrm{SnO}_{2}$ immediately below, and that the $\mathrm{Sb}$ (III) ions do not inject electrons into the conduction band. Instead $\mathrm{Sb}(\mathrm{III})$ ions trap a pair of electrons, giving rise to a lone pair surface state where the electron density sits in a sp hybrid state projecting from the surface. The lone pairs can act as two electron donors, allowing bonding to single oxygen atoms which are two electron acceptors. The chemisoption of oxygen atoms on these surface sites is analogous to the transformation between molecular $\mathrm{P}_{4} \mathrm{O}_{6}$ and $\mathrm{P}_{4} \mathrm{O}_{10}$, where in the latter each $\mathrm{P}$ atom of the $\mathrm{P}_{4} \mathrm{O}_{6}$ tetrahedron accommodates an extra oxygen atom. Increasing the calcination temperature favours this segregation of $\mathrm{Sb}(\mathrm{III})$ and $(\mathrm{V})$ with an increasing fraction of $\mathrm{Sb}(\mathrm{III})^{31}$. The data in Table ST3 support the latter assertion, with more $\mathrm{Sb}$ (III) segregating to the surface and hence being detected by XPS when calcined at $700{ }^{\circ} \mathrm{C}$ compared to $400{ }^{\circ} \mathrm{C}$.

Figure 2 shows plots of the rate of ozone evolution vs the $\mathrm{Sb}$ (III) content of the samples: as may be seen from the figure and Table ST3, the $\mathrm{Ni} / \mathrm{Sb}-\mathrm{SnO}_{2}$ samples calcined at $400{ }^{\circ} \mathrm{C}$ were inactive with respect to the electrochemical generation of $\mathrm{O}_{3}$, whereas the samples calcined at $700{ }^{\circ} \mathrm{C}$ were all active. This, then, begs the question as to whether the content of $\mathrm{Sb}$, and of $\mathrm{Sb}$ (III) in particular given its location at the surface, influences ozone activity. Further, Sun and co-workers ${ }^{31}$ postulate that oxygen adsorbs at oxygen vacancies associated with $\mathrm{Sb}(\mathrm{III})$.

Given the key steps in the generally-accepted mechanism for ozone generation ${ }^{1,4,6,20}$ are of the form:

$$
\begin{aligned}
& \mathrm{H}_{2} \mathrm{O} \rightarrow \mathrm{OH}_{\mathrm{ads}}+\mathrm{H}^{+}+\mathrm{e}^{-} \\
& \mathrm{OH}_{\mathrm{ads}} \rightarrow \mathrm{O}_{\mathrm{ads}}+\mathrm{H}^{+}+\mathrm{e}^{-} \\
& \mathrm{O}_{\text {ads }}+\mathrm{O}_{\mathrm{ads}} \rightarrow \mathrm{O}_{2 \text { ads }} \rightarrow \mathrm{O}_{2} \\
& \mathrm{O}_{\text {ads }}+\mathrm{O}_{2 \mathrm{ads}} \rightarrow \mathrm{O}_{3 \text { ads }} \rightarrow \mathrm{O}_{3}
\end{aligned}
$$

clearly the ability to adsorb molecular oxygen, and for this to compete effectively with the adsorption of water, is key to the production of ozone. However formation of ozone must clearly compete with desorption of oxygen formed in step 3. Sun et al.$^{31}$ state that the binding energy of water to $\mathrm{Sb}-\mathrm{SnO}_{2}$ is less than at $\mathrm{SnO}_{2}$ itself, and that lattice oxygen becomes more available. The trend observed with the nanoparticulate samples supports the postulate that $\mathrm{Sb}(\mathrm{III})$ in some way enhances or facilitates ozone activity. 
It was possible to detect $\mathrm{Ni}$ in the ceramic anodes (c- $1.0 \% \mathrm{Ni} / \mathrm{Sb}-\mathrm{SnO}_{2} 460{ }^{\circ} \mathrm{C}$, prepared by dipcoating) by XPS. Typical spectra are shown in Figure 3 showing the Ni $2 p$ region for an untested ceramic anode, and an identical anode after being employed to electrolyze $0.5 \mathrm{M} \mathrm{H}_{2} \mathrm{SO}_{4}$ for 30 seconds in three separate experiments in the cuvette cell at a cell voltage of $2.7 \mathrm{~V}$. In contrast to Grosvenor and co-workers ${ }^{34}$, the observed peak shapes cannot be synthesised as a superposition of $\mathrm{Ni}$ (II) and $\mathrm{Ni}$ (III) but the prevalence of spectral weight within the data towards higher binding energy is suggestive of the dominance of $\mathrm{Ni}$ (III). As can be seen from the figure, most of the Ni was lost from the surface following electrolysis $(0.7 \% \mathrm{Ni}$ in untested sample compared to $0.1 \%$ after testing), whilst ca. $11.7 \pm 0.5 \% \mathrm{Sb}$ was lost, suggesting dissolution as well as physical loss of $\mathrm{Ni}$. The possibility that $\mathrm{Ni}$ (III) is the active site for ozone evolution at $\mathrm{Ni} / \mathrm{Sb}-\mathrm{SnO}_{2}$ anodes has been postulated ${ }^{17-19}$, but not proven as this species has not, hitherto, been detected at anode surfaces. Thus, for example, Wang et al. ${ }^{18}$ presented XPS data on $\mathrm{Ni} / \mathrm{Sb}-\mathrm{SnO}_{2}$ anodes and claimed that a peak at $855.6 \mathrm{eV}$ was due to the $\mathrm{Ni} 2 \mathrm{p}_{3 / 2}$ peak of $\mathrm{Ni}(\mathrm{III})$. However, no peak was apparent in the published spectrum. Yang and co-workers ${ }^{19}$ postulated that a peak at $856.3 \mathrm{eV}$ was due to $\mathrm{Ni}(\mathrm{OH})_{2}$ or $\mathrm{NiO}$.

The fact that $\mathrm{Ni}$ could not be detected in the $\mathrm{Ni} / \mathrm{Sb}-\mathrm{SnO}_{2}$ anodes, yet those calcined at $700{ }^{\circ} \mathrm{C}$ were all active for ozone generation, is interesting, as is the fact that the anodes are reasonably durable when immersed in acid electrolytes under oxidising conditions. As an example of the durability of the ceramic anodes, Figure 4 shows the results of an experiment in which a ceramic anode, prepared by exactly the same method as those in Figure 3, was employed to electrolyze $0.5 \mathrm{M} \mathrm{H}_{2} \mathrm{SO}_{4}$ for 30 seconds in three separate experiments at 9 am and $5 \mathrm{pm}$ each day (apart from the weekend) for 11 days. Between each set of experiments, the electrode was left immersed in $0.5 \mathrm{M} \mathrm{H}_{2} \mathrm{SO}_{4}$. As can be seen from the figure, the current density remained at $137 \pm 16 \mathrm{~mA} \mathrm{~cm}^{-2}$ and the current efficiency at $10.3 \pm 0.7 \%$ over the testing period. In fact, we have previously reported that anodes prepared using an identical method except using $\mathrm{NiO}$ and $\mathrm{Sb}_{2} \mathrm{O}_{3}$ instead of the chloride salts ${ }^{13,16}$ remained highly active for up to 600 hours during the continuous electrolysis of $1 \mathrm{M} \mathrm{HClO}_{4}$ at $100 \mathrm{~mA} \mathrm{~cm}^{-2}$. In addition, when the anodes failed, they did so because of the catastrophic spallation of the Ni/Sb$\mathrm{SnO}_{2}$ coating from the Ti substrate. It is clear from the literature on the dissolution of Ni oxides in acidic electrolytes ${ }^{35-36}$ and on the basis of the potentials of the various Ni species ${ }^{37-39}$ that Ni(III) will dissolve at open circuit or low potentials during extended immersion in acid electrolytes, whilst $\mathrm{Ni}(\mathrm{II})$ will dissolve under all conditions in such electrolyte. The fact that, during the test in Figure 4 and those reported in references ${ }^{13,16}$, the anodes remained active strongly suggests that the nickel is present below the surface, with its (strong) influence on ozone activity taking place via the ligand effect $^{40}$. Any nickel present on the surface simply dissolves away and is not responsible for ozone activity

\section{$T G A$}

Figure 5(a) shows the thermogravimetric response of the nanopowders produced by the hydrothermal method and calcined at $400{ }^{\circ} \mathrm{C}$, and Figure 5(b) the corresponding differential plots. The $\mathrm{SnO}_{2}$ data have been discussed previously ${ }^{21}$. In brief, based on the differential TGA response and IR data, the differential plot for $\mathrm{SnO}_{2}$ calcined at $400{ }^{\circ} \mathrm{C}$ in Figure 5(a) can be considered in terms of five temperature regions: (I) $0-$ ca. $65^{\circ} \mathrm{C}$, (II) $65-150{ }^{\circ} \mathrm{C}$, (III) $150-450{ }^{\circ} \mathrm{C}$, (IV) $450{ }^{\circ} \mathrm{C}-900{ }^{\circ} \mathrm{C}$ and $(\mathrm{V}) 900-25^{\circ} \mathrm{C}$, and these are employed to interpret the $\mathrm{Sb}-\mathrm{SnO}_{2}$ and Ni/Sb$\mathrm{SnO}_{2}$ data. The samples calcined at $700{ }^{\circ} \mathrm{C}$ showed very similar behaviour (see Figures $\mathrm{S} 4$ (a) and (b)), except with smaller mass changes compared to those observed using the $400{ }^{\circ} \mathrm{C}$ samples.

It is clear from Figures 5(a) and S4(a) that doping with Sb has a significant effect upon the TGA response. Thus, whilst the general structures of the various plots in the figures are very similar in that all show the five regions discussed above, the total mass losses on heating to $900{ }^{\circ} \mathrm{C}$ were 
higher for the Sb-containing samples than the undoped $\mathrm{SnO}_{2}$ nanopowders. Thus, for the samples calcined at $400{ }^{\circ} \mathrm{C}$, the total mass loss observed for $\mathrm{SnO}_{2}$ was ca. $1.5 \%$ compared to $3-3.8 \%$ for the Sb-containing samples; it does not appear that the Ni content had any significant effect on this mass loss. This is also seen clearly in the differential plots (Figures. 5(b) and S4(b)), with a large increase in the first peak due to the loss of water and a shift of ca. $5^{\circ} \mathrm{C}$ to higher temperatures, along with the appearance of peaks near $266{ }^{\circ} \mathrm{C}, 333{ }^{\circ} \mathrm{C}$ and $515^{\circ} \mathrm{C}$ in addition to the peak near $450{ }^{\circ} \mathrm{C}$ in the response of the undoped $\mathrm{SnO}_{2}$. Given the simplicity of the system and based on the literature ${ }^{41}$ these peaks at temperatures $>150{ }^{\circ} \mathrm{C}$ must be associated with the dehydroxylation of the surfaces of the samples (see below), with the additional features due to the presence of Sb.

Regions (I) and (II)

Mass spectroscopy showed only the evolution of water $(\mathrm{m} / \mathrm{z}=18)$ from $\mathrm{SnO}_{2}{ }^{21}$ and $\mathrm{Sb}-\mathrm{SnO}_{2}$ samples calcined at $400{ }^{\circ} \mathrm{C}$ and $700{ }^{\circ} \mathrm{C}$ with maxima corresponding to the minima in the corresponding differential plots (eg. Figures 5(b) and S4(b)). Based on the model of Morishige and co-workers ${ }^{42}$ and Morimoto et al. ${ }^{43-44}$, the mass loss in region (I) of the $\mathrm{SnO}_{2}$ response was attributed to the loss of physisorbed water from $\operatorname{Sn}(100)$ facets, having little or no hydrogen bonding to the $\mathrm{OH}$ groups thereon due to the $\mathrm{H}$ atoms of the latter occupying the hollows between the $\mathrm{O}$ atoms, and mass loss in region (II) was due to the loss of water hydrogen-bonded to $\mathrm{OH}$ groups on the (111) and (110) facets of the $\mathrm{SnO}_{2}$. Overall, assuming an area of ca. $15 \times 10^{-20} \mathrm{~m}^{2}$ for the water molecule ${ }^{41}$ the total mass loss in regions (I) and (II) corresponded to the loss of $0.37^{21}$ monolayers of water. Table ST4 summarizes the coverage of the nanopowders by water at $25{ }^{\circ} \mathrm{C}$ using the same method and assumptions, and Figure 6 shows a plot of the mass of $\mathrm{H}_{2} \mathrm{O}$ released from the nanopowder samples calcined at $400^{\circ} \mathrm{C}$ as a function of their total surface areas calculated from the crystallite sizes obtained from the XRD measurements; the corresponding data for the samples calcined at $700{ }^{\circ} \mathrm{C}$ are shown in Figure S5. In both cases, the plots are fairly linear, supporting the postulate that water has access to the internal surface area within the $\mathrm{SnO}_{2}$ particles.

As expected, the total surface areas of the samples calcined at $700{ }^{\circ} \mathrm{C}$ are lower than the $400{ }^{\circ} \mathrm{C}$ samples, and the amount of adsorbed water released is correspondingly lower. It is clear from Table ST4 that the addition of Sb significantly increases the coverage by water: the undoped samples show a coverage of 0.1 and 0.03 for the powders calcined at $400{ }^{\circ} \mathrm{C}$ and $700{ }^{\circ} \mathrm{C}$, respectively: addition of $\mathrm{Sb}$ increases these to 0.21 and 0.13 , respectively. Dusastre and Williams ${ }^{24}$, following on from the work of Brown and Patterson ${ }^{45}$ postulate the surface enrichment of $\mathrm{SnO}_{2}$ by $\mathrm{Sb}$ (III), and that water preferentially adsorbs at the substituted sites; the marked increase in adsorbed water in Table ST4 on doping the $\mathrm{SnO}_{2}$ samples with $\mathrm{Sb}$ supports this theory. Further, the authors suggest that oxygen adsorbs on oxygen vacancies: in the absence of $\mathrm{Sb}$, the active sites are $\mathrm{Sn}$ (II) ions associated with oxygen vacancies, whilst in the presence of $\mathrm{Sb}$, the sites are $\mathrm{Sb}$ (III) ions associated with the vacancies; the adsorption of oxygen competes with that of water, with the binding energy of water on these vacancies being less on $\mathrm{Sb}$ (III) sites than $\mathrm{Sn}$ (II). Oxygen adsorption is discussed in further detail below. Figure 7 shows a plot of the water coverage as a function of the Ni content in the precursor solutions: clearly, addition of $\mathrm{Ni}$ has little effect upon water coverage for samples calcined at $700{ }^{\circ} \mathrm{C}$, but a marked effect upon those calcined at $400{ }^{\circ} \mathrm{C}$, with the coverage rising to a maximum at $1 \%$. This suggests that one reason for the inactivity of the samples calcined at $400{ }^{\circ} \mathrm{C}$ is that the coverage of water is too high, and prevents the adsorption of molecular oxygen: from the data in Table ST3 this links in to the lower amount of $\mathrm{Sb}$ (III) on the $400{ }^{\circ} \mathrm{C}$ samples. It does not seem unreasonable to postulate that a minimum surface coverage by $\mathrm{Sb}$ (III) is required to ensure sufficient adsorbed molecular oxygen can compete with water for the active sites. A plot of $\mathrm{Sb}$ (III) content vs water coverage (Figure 8) supports the postulate that too high a water coverage is linked to low $\mathrm{Sb}(\mathrm{III})$ and zero ozone activity. 
Regions (III) and (IV)

In our previous work, it was postulated ${ }^{21}$ that the process taking place in regions (III) and (IV) was the dehydration of $\mathrm{SnOH}$ groups on the surface according to:

$$
2 \mathrm{SnOH} \rightarrow \mathrm{Sn}-\mathrm{O}-\mathrm{Sn}+\mathrm{H}_{2} \mathrm{O}
$$

Table ST5 shows the ratio of the $\mathrm{OH}$ groups to surface $\mathrm{Sn}$ atoms for the $\mathrm{SnO}_{2}, \mathrm{Sb}-\mathrm{SnO}_{2}$ and Ni/Sb$\mathrm{SnO}_{2}$ nanopowders assuming $9.1 \times 10^{14} \mathrm{Sn}$ atoms per $\mathrm{cm}^{2}{ }^{46}$, calculated on the basis of equation (5), crystallite surface areas calculated from the XRD data and the mass losses between $150{ }^{\circ} \mathrm{C}$ and $900{ }^{\circ} \mathrm{C}$ in the TGA experiments. If the value for the $\mathrm{Sb}-\mathrm{SnO}_{2}$ calcined at $400{ }^{\circ} \mathrm{C}$ is taken as an outlier, then the data suggest that the addition of $\mathrm{Sb}$ and $\mathrm{Ni}$ to $\mathrm{SnO}_{2}$ has very little effect upon the hydroxylation of the surface: however, the calcination temperature does have a marked effect, almost halving the number of $\mathrm{OH}$ species per $\mathrm{Sn}$ atom when increasing the calcination temperature from 400 to $700{ }^{\circ} \mathrm{C}$. This is interesting to note given that the $\mathrm{Ni} / \mathrm{Sb}-\mathrm{SnO}_{2}$ samples calcined at $700{ }^{\circ} \mathrm{C}$ are all active with respect to ozone generation and the corresponding samples calcined at $400{ }^{\circ} \mathrm{C}$ are inactive and, as reported in our previous paper, the presence of $\mathrm{OH}$ adsorbed on the (111) and (110) facets of $\mathrm{Sn}$ encourages water adsorption due to hydrogen bonding. Further, $\mathrm{Sb}-\mathrm{SnO} \mathrm{S}_{2}$ anodes tend to fail, sometimes after fairly short electrolysis times, failure being defined as the cell voltage rising to eg. $5 \mathrm{~V}$ during constant current electrolysis. This failure has been attributed to the passivation of the electrode surface ${ }^{32,47-49}$; for example, Montilla and co-workers ${ }^{32,48-49}$ attribute the inactivation of $\mathrm{Sb}_{-} \mathrm{SnO}_{2}$ electrodes to the formation of a passivating $\mathrm{SnOH}$ layer on the surface.

Region (V) and oxygen uptake In our previous paper ${ }^{21}$ we attributed the mass increase in region (V), at least from 900 to $150{ }^{\circ} \mathrm{C}$, to the uptake of molecular oxygen via adsorption, simply on the basis of the chemical simplicity of the system. Figure S6 shows plots of the mass gain in region (V) for the various samples. It is not clear from the figure that there is any difference between the mass gain in region $(\mathrm{V})$ that relates to electrode composition.

Previously, we attributed the inflexion in the TGA response of $\mathrm{SnO}_{2}$ in Figure 5(a) marked with *, and similarly marked on Figure 5(b), to the uptake of oxygen ${ }^{50}$ which was largely masked due to the processes associated with the dehydration and dehydroxylation of the surface. In order to explore this, we carried out sequential heating and cooling cycles, and Figure 9(a) shows the typical data so obtained using the $\mathrm{SnO}_{2}$ sample calcined at $400{ }^{\circ} \mathrm{C}$, whilst Figure 9(b) shows the $4^{\text {th }}$ heating and cooling cycle for the $\mathrm{SnO}_{2}, \mathrm{Sb}-\mathrm{SnO}_{2}$ and $\mathrm{Ni} / \mathrm{Sb}-\mathrm{SnO}_{2}$ samples calcined at $400{ }^{\circ} \mathrm{C}$. The analogous spectra to those in Figure 9(b) for the samples calcined at $700{ }^{\circ} \mathrm{C}$ are shown in Figure S7. As can be seen, all the responses are similar, and from cycle 2 onwards, all (eventually) return to $100 \%$ and hence the processes responsible for the behaviour in Figure 9(b) and S7 are reversible. The similarity between the Sb-containing samples is emphasised in Figures 10 and S8 which show the differential plots of the data in Figure 9(b) and S7. We attribute the increase in mass to the reversible uptake of oxygen at the crystallite boundaries ${ }^{50}:$ it is generally accepted that oxygen adsorbs on the surface of $\mathrm{SnO}_{2}$, and can then diffuse into the inner grain boundary (i.e. crystallite) surfaces of porous $\mathrm{SnO}_{2}{ }^{46,51}$. The adsorbed $\mathrm{O}_{2}$ that was initially gained up to $350-500{ }^{\circ} \mathrm{C}$ is then lost on heating to $900{ }^{\circ} \mathrm{C}$, with additional loss of oxygen - possibly due to oxygen desorbing from the crystallite surfaces within the grains. On cooling, the initial state is regained.

Table ST6 shows the number of oxygen molecules adsorbed per Sn atom during the initial stages of heating in Figures 9(b) and S7, and the nett loss of $\mathrm{O}_{2}$ molecules per Sn atom on heating from $25{ }^{\circ} \mathrm{C}$ 
to $900{ }^{\circ} \mathrm{C}$, assuming $9.1 \times 10^{14} \mathrm{Sn}$ atoms $\mathrm{cm}^{-2} 46$ and using the XRD crystallite surface areas. Clearly, the addition of $\mathrm{Sb}$ has a very significant effect upon $\mathrm{O}_{2}$ uptake, which drops by a factor of ca. 6 for both the samples calcined at $400{ }^{\circ} \mathrm{C}$ and those calcined at $700{ }^{\circ} \mathrm{C}$. Addition of Ni then increases the uptake slightly in both cases. Considering only the $\mathrm{Ni} / \mathrm{Sb}-\mathrm{SnO}_{2}$ samples in Table ST6, the ozone-active samples calcined at $700{ }^{\circ} \mathrm{C}$ show a higher uptake of oxygen than those calcined at $400{ }^{\circ} \mathrm{C}$, in agreement with our postulate that molecularly adsorbed $\mathrm{O}_{2}$ is key to ozone activity. Figure 11 shows a plot of the $\mathrm{O}_{2}$ uptake vs the $\mathrm{Sb}$ (III) content: as can be seen, it appears that there is, again, a correlation. Interestingly, and in contrast to the data in Figures 9(b) and S7, the fully hydrated samples do not show an initial increase in mass on heating, see Figures 5(a) and S4(a), suggesting that water inhibits $\mathrm{O}_{2}$ adsorption, in agreement with the discussion above.

\section{The $\mathrm{Sb}-\mathrm{SnO}_{2} / \mathrm{Ni}$ samples}

As can be seen from Figures $\mathrm{S} 1$ (c) (i) and (ii), there is no change in the colour of the $\mathrm{Sb}-\mathrm{SnO}_{2}$ $700{ }^{\circ} \mathrm{C}$ sample on adding the $\mathrm{Ni}$ and heating again to $700{ }^{\circ} \mathrm{C}$, as may be expected. The XRD data are very similar to those of the other samples, showing only cassiterite. The $\mathrm{V}_{\mathrm{BET}} / \mathrm{V}_{\mathrm{XRD}}$ of the 700 ${ }^{\circ} \mathrm{C} \mathrm{Sb}-\mathrm{SnO}_{2} / 0.1 \% \mathrm{Ni} 700{ }^{\circ} \mathrm{C}$ powder was 5.5 , ca. $3 \mathrm{x}$ lower than those of the $\mathrm{Ni} / \mathrm{Sb}-\mathrm{SnO}_{2} 700{ }^{\circ} \mathrm{C}$ samples. This implies that the elimination of internal grain boundaries is promoted by the second calcination. As can be seen from Table ST3, all three $\mathrm{Sb}-\mathrm{SnO}_{2} / \mathrm{Ni}$ samples were active for $\mathrm{O}_{3}$, with the samples calcined at $700{ }^{\circ} \mathrm{C}$ after $\mathrm{Ni}$ addition both giving the same rate of $\mathrm{O}_{3}$ at ca. $15-16$ nanomoles s ${ }^{-1}$, whilst the sample calcined at $460{ }^{\circ} \mathrm{C}$ after $\mathrm{Ni}$ addition gives a rate ca. half those of the other two samples. The $\mathrm{Ni}$ content at the surface is ca. $2-3$ times less for $700{ }^{\circ} \mathrm{C} \mathrm{Sb}$ $\mathrm{SnO}_{2} / 0.01 \% \mathrm{Ni} 700{ }^{\circ} \mathrm{C}$ compared to $700{ }^{\circ} \mathrm{C} \mathrm{Sb}-\mathrm{SnO}_{2} / 0.1 \% \mathrm{Ni} 700{ }^{\circ} \mathrm{C}$, and the latter is comparable to that of the $700{ }^{\circ} \mathrm{C} \mathrm{Sb}-\mathrm{SnO}_{2} / 0.1 \% \mathrm{Ni} 460{ }^{\circ} \mathrm{C}$ sample. This is not surprising based on the model developed above: addition of a Ni solution of higher concentration yields more surface $\mathrm{Ni}$, but this is not the species responsible for $\mathrm{O}_{3}$ activity, and simply dissolves away on immersion in acidic electrolyte. The lower $\mathrm{O}_{3}$ activity of the $700{ }^{\circ} \mathrm{C} \mathrm{Sb}-\mathrm{SnO}_{2} / 0.1 \% \mathrm{Ni} 460{ }^{\circ} \mathrm{C}$ may be related to the lower $\mathrm{Sb}$ (III) content. To our knowledge, this is the first report of ozone generation by $\mathrm{Ni} / \mathrm{Sb}-\mathrm{SnO}_{2}$ nanopowder anodes.

Figures 12(a) and (b) show plots of current efficiency and current density, respectively, vs Ni the content of the $700{ }^{\circ} \mathrm{C} \mathrm{Sb}-\mathrm{SnO}_{2} / \mathrm{Ni} \mathrm{T}_{2}$ samples with $\mathrm{T}_{2}=460{ }^{\circ} \mathrm{C}$ and $700{ }^{\circ} \mathrm{C}$. It is clear that the initial temperature employed to calcine the $\mathrm{Sb}-\mathrm{SnO}_{2}$ nanopowders $\left(\mathrm{T}_{1}\right)$ essentially determines the current efficiency, with the subsequent calcination temperature $\left(\mathrm{T}_{2}\right)$ of the $700{ }^{\circ} \mathrm{C} \mathrm{Sb}-\mathrm{SnO}_{2} / \mathrm{Ni} \mathrm{T}_{2}$ having little effect. In contrast, $\mathrm{T}_{2}$ had a marked effect upon the current density observed. These data suggest that, in agreement with the discussions above, $\mathrm{Sb}$ is not simply important to induce electronic conductivity, but also plays a significant role in the surface chemistry, and in particular, with respect to ozone generation. In addition, it is clear from the figures that, despite a hundredfold difference in the amount of $\mathrm{Ni}$ actually added to the surface, there is a much smaller difference in the observed current densities and efficiencies, supporting the postulate that the $\mathrm{Ni}$ at the surface simply dissolves away and is unimportant with respect to ozone generation: it is the subsurface $\mathrm{Ni}$, which cannot be detected, that catalyses $\mathrm{O}_{3}$ evolution. The latter is supported by the data for the Ni$\mathrm{Sb} / \mathrm{SnO}_{2}$ samples calcined at $700{ }^{\circ} \mathrm{C}$ in Figure 2, all of which show comparable activities for $\mathrm{O}_{3}$, despite a fivefold difference in Ni concentration in the precursor solutions, the Ni undetected by XPS.

Figures $\mathrm{S} 6$ and $\mathrm{S} 7$ show that the TGA responses of the $700{ }^{\circ} \mathrm{C} \mathrm{Sb}-\mathrm{SnO}_{2} / 0.1 \% \mathrm{Ni} 700{ }^{\circ} \mathrm{C}$ closely resemble those of the $\mathrm{Sb}-\mathrm{SnO}_{2}$ and $\mathrm{Ni} / \mathrm{Sb}-\mathrm{SnO}_{2}$ samples calcined at $700{ }^{\circ} \mathrm{C}$, differing only in magnitude. 


\section{Model}

To integrate the observations reported above, we propose a model for the surface behaviour of Sb$\mathrm{SnO}_{2}$, based on the concept illustrated in Figure 13. BET surface area measurements give information about the particle surface area as nitrogen is unable to access internal grain boundary interfaces beneath the external particle surface at $77 \mathrm{~K}$. By way of contrast XRD gives an estimate of crystallite size, limited by the internal interfaces between domains of identical crystallographic orientation. To explain the experimental observations reported in this paper, we propose that water (in the form of $\mathrm{OH}$ ) accesses internal crystallite surfaces through diffusion of $\mathrm{OH}$, and this then controls the formation of $\mathrm{O}_{3}$. However, given that $\mathrm{N}_{2}$ cannot access the internal crystallite surfaces it is unlikely that $\mathrm{O}_{3}$ can be generated on these and subsequently diffuse to the particle surface. Instead, we propose that $\mathrm{O}_{3}$ is generated at particle surfaces from $\mathrm{OH}$ that is able to diffuse via crystallite surfaces. The diffusion of water in rutile $\mathrm{TiO}_{2}$, which has the same crystal structure as $\mathrm{SnO}_{2}$, is well known to take place (see, for example ${ }^{52-53}$ ). That the mobile species is in fact the $\mathrm{OH}$ radical was shown by the detailed investigations of oxygen diffusion in rutile by Moore et al. ${ }^{54}$.

In addition to the morphological effects, there is clearly a synergic interaction between nickel and antimony because $\mathrm{Sb}$-doped $\mathrm{SnO}_{2}$ is inactive with respect to ozone evolution in the absence of Ni. On the other hand $\mathrm{Ni}$ doping by itself does not give the sort of conductive oxide required for use as an electrode. Formally $\mathrm{Ni}^{2+}$ would act as a two-hole p-type dopant, but $\mathrm{SnO}_{2}$ is not amenable to $\mathrm{p}$ type doping. This leads to the following considerations. Ni(II) has almost exactly the same ionic radius as $\mathrm{Sn}(\mathrm{IV})$ but clearly has a lower charge. $\mathrm{Ni}$ (II) incorporation into subsurface region of $\mathrm{SnO}_{2}$ can be compensated by oxygen vacancies to maintain charge neutrality. We suggest that these vacancies may promote dissociation of $\mathrm{O}_{2 \text { ads }}$ appearing in step (2) in the scheme discussed earlier: a single $\mathrm{O}$ atom remains chemisorbed to donor $\mathrm{Sb}$ (III) sites and the second $\mathrm{O}$ atom diffuses onto a bulk oxygen vacancy site in the subsurface region where it can trap two electrons from the conduction band to give $\mathrm{O}^{2-}$ sub. This will inhibit desorption of oxygen. However we speculate that the process is reversible so that $\mathrm{O}$ may shuttle back to the surface. Instead of concerted addition of $\mathrm{O}_{2}$ to $\mathrm{OH}$ we may envisage an alternative sequence of steps:

$$
\begin{aligned}
& \mathrm{O}_{2 \text { ads }}+2 \mathrm{e}^{-} \mathrm{CB} \rightarrow \mathrm{O}_{\text {ads }}+\mathrm{O}^{2-}{ }_{\text {sub }} \\
& \mathrm{OH}_{\text {ads }}+\mathrm{O}_{\text {ads }} \rightarrow \mathrm{HO}_{2 \text { ads }} \\
& \mathrm{HO}_{2 \text { ads }}+\mathrm{O}^{2-} \text { sub } \rightarrow \mathrm{HO}_{3 \text { ads }}+2 \mathrm{e}^{-} \mathrm{CB} \\
& \mathrm{HO}_{3 \text { ads }} \rightarrow \mathrm{O}_{3}+\mathrm{H}^{+}+\mathrm{e}^{-}
\end{aligned}
$$

This proposal is speculative and does not involve participation by $\mathrm{Ni}(\mathrm{III})$ as has been proposed elsewhere; on the other hand, it does explain the obvious synergy as the mechanism requires both subsurface oxygen vacancies and electrons in the conduction band. The proposed synergy in ozone generation between subsurface oxygen vacancies and surface lone pair cations in a metallic oxide also helps explain the activity of $\mathrm{PbO}_{2}$ as an anode. Both $\mathrm{SnO}_{2}$ and $\mathrm{PbO}_{2}$ adopt the rutile structure, but intrinsically $\mathrm{PbO}_{2}$ tolerates a much higher concentration of bulk oxygen vacancies: recent neutron diffraction experiments supported by first principle calculations of defect formation energies show that in commercial $\mathrm{PbO}_{2}$ powder, up to $1.6 \%$ of the oxygen sites may be empty ${ }^{55}$. These vacancies act as two electron donors, so that $\mathrm{PbO}_{2-\mathrm{x}}$ is a metallic conductor. At the same time the facile reduction of $\mathrm{PbO}_{2}$ at the surface will promote formation of surface $\mathrm{Pb}$ (II) cations which support an electron lone pair. Thus in $\mathrm{PbO}_{2-x}$ oxygen vacancies provide all three ingredients required by our mechanism. In NATO anodes, bulk and segregated $\mathrm{Sb}$ and $\mathrm{Ni}$ are each required as the intrinsic $\mathrm{O}$ vacancy concentration in $\mathrm{SnO}_{2}$ is much lower. Bulk $\mathrm{Sb}(\mathrm{V})$ acts as the electron donor resulting in metallic behaviour, surface $\mathrm{Sb}$ (III) acts as the surface lone pair cation and bulk $\mathrm{Ni}$ (II) is required to promote formation of oxygen vacancies below the surface. 


\section{Conclusions}

In $\mathrm{Ni}$ and $\mathrm{Sb}$ co-doped $\mathrm{SnO}_{2}$, the $\mathrm{Ni}$ and $\mathrm{Sb}$ ions replace $\mathrm{Sn}(\mathrm{IV})$ ions with no effect upon the unit cell dimensions. The $\mathrm{Sb}$ is present as $\mathrm{Sb}(\mathrm{V})$ in the crystal bulk where it acts as a one electron donor, with segregation of $\mathrm{Sb}$ (III) to the surface, whilst Ni occupies $\mathrm{Sn}$ (IV) sites in the subsurface region at concentrations below the level of detectability by XPS. Sb(V) confers electronic conductivity on $\mathrm{SnO}_{2}$ whilst both $\mathrm{Sb}(\mathrm{III})$ and subsurface $\mathrm{Ni}$ are essential for ozone generation. $\mathrm{Ni}(\mathrm{II})$ incorporation is compensated by oxygen vacancies which promote the dissociation of adsorbed molecular oxygen to give single oxygen atoms adsorbed on $\mathrm{Sb}$ (III) sites. These atoms react with adsorbed hydroxyl molecules to produce $\mathrm{O}_{3}$. The $\mathrm{Ni} / \mathrm{Sb}-\mathrm{SnO}_{2}$ particles individually are composed of several crystallites, and ozone generation is controlled by the diffusion of $\mathrm{OH}$ radicals to the internal crystallite surfaces.

For the first time, $\mathrm{Ni} / \mathrm{Sb}-\mathrm{SnO}_{2}$ nanopowders have been made that are highly active and selective towards the electrochemical generation of ozone. The synthesis of these nanopowders has not been optimised, but with such optimisation our approach should lead to the production of compact, zero gap and energy efficient electrochemical systems capable of treating real waters.

\section{Acknowledgements}

SM would like to thank the Thai Government for the award of a Royal Thai Scholarship. The authors would like to thank Mr. Bernard Bowler for his expertise in thermogravimetric analysis and Ms. Emma Shuttleworth for her invaluable help with the ozone measurements.

\section{References}

1. Silva, L. M. d.; Jardim, W. F., Trends and Strategies of Ozone Application in Environmental Problems. Química Nova 2006, 29, 310-317.

2. Khoudja, R. Y.; Xu, Y.; Li, T.; Zhou, C., Better Ivf Outcomes Following Improvements in Laboratory Air Quality. Journal of Assisted Reproduction and Genetics 2013, 30, 69-76.

3. Siemens, W., Ueber Die Elektrostatische Induction Und Die Verzögerung Des Stroms in Flaschendrähten. Annalen der Physik 1857, 178, 66-122.

4. Christensen, P. A.; Yonar, T.; Zakaria, K., The Electrochemical Generation of Ozone: A Review. Ozone-Science \& Engineering 2013, 35, 149-167.

5. Kirk-Othmer, Encyclopedia of Chemical Technology, 5th ed.. ed.; Hoboken, N.J. : WileyInterscience: Hoboken, N.J., 2004; Vol. 17.

6. De Sousa, L. G.; Franco, D. V.; Da Silva, L. M., Electrochemical Ozone Production Using Electrolyte-Free Water for Environmental Applications. Journal of Environmental Chemical Engineering 2016, 4, 418-427.

7. Arihara, K.; Terashima, C.; Fujishima, A., Application of Freestanding Perforated Diamond Electrodes for Efficient Ozone-Water Production. Electrochemical and Solid-State Letters 2006, 9, D17-D20.

8. Kraft, A.; Stadelmann, M.; Wünsche, M.; Blaschke, M., Electrochemical Ozone Production Using Diamond Anodes and a Solid Polymer Electrolyte. Electrochemistry Communications 2006, 8, 883-886.

9. Arihara, K.; Terashima, C.; Fujishima, A., Electrochemical Production of HighConcentration Ozone-Water Using Freestanding Perforated Diamond Electrodes. Journal of The Electrochemical Society 2007, 154, E71-E75.

10. Chan, K. Y.; Cheng, S. A., Electrolytic Generation of Ozone on an Antimony-Doped Tin Dioxide Coated Electrode. Electrochemical and solid-state letters 2004, 7, D4-D6. 
11. Wang, Y. H.; Cheng, S. A.; Chan, K. Y.; Li, X. Y., Electrolytic Generation of Ozone on Antimony- and Nickel-Doped Tin Oxide Electrode. Journal of the Electrochemical Society 2005, 152, D197-D200.

12. Christensen, P. A.; Lin, W. F.; Christensen, H.; Imkum, A.; Jin, J. M.; Li, G.; Dyson, C. M., Room Temperature, Electrochemical Generation of Ozone with 50\% Current Efficiency in $0.5 \mathrm{~m}$ Sulfuric Acid at Cell Voltages <3v. Ozone: Science \& Engineering 2009, 31, 287-293.

13. Christensen, P. A.; Zakaria, K.; Christensen, H.; Yonar, T., The Effect of Ni and Sb Oxide Precursors, and of Ni Composition, Synthesis Conditions and Operating Parameters on the Activity, Selectivity and Durability of Sb-Doped $\mathrm{SnO}_{2}$ Anodes Modified with Ni. Journal of the Electrochemical Society 2013, 160, H405-H413.

14. Wang, Y. H.; Cheng, S.; Chan, K. Y., Synthesis of Ozone from Air Via a PolymerElectrolyte-Membrane Cell with a Doped Tin Oxide Anode. Green Chemistry 2006, 8, 568572.

15. Cui, Y.; Wang, Y.; Wang, B.; Zhou, H.; Chan, K.-Y.; Li, X.-Y., Electrochemical Generation of Ozone in a Membrane Electrode Assembly Cell with Convective Flow. Journal of The Electrochemical Society 2009, 156, E75-E80.

16. Zakaria., K. Industrial Wastewater Treatment Using Electrochemically Generated Ozone. Ph.D. Thesis, Newcastle University, Newcastle Upon Tyne, 2013.

17. Basiriparsa, J.; Abbasi, M., High-Efficiency Ozone Generation Via Electrochemical Oxidation of Water Using Ti Anode Coated with Ni-Sb-SnO 2 . Journal of Solid State Electrochemistry 2012, 16, 1011-1018.

18. Wang, Y. H.; Chan, K. Y.; Li, X. Y.; So, S. K., Electrochemical Degradation of 4Chlorophenol at Nickel-Antimony Doped Tin Oxide Electrode. Chemosphere 2006, 65, 1087-1093.

19. Yang, S. Y.; Choo, Y. S.; Kim, S.; Lim, S. K.; Lee, J.; Park, H., Boosting the Electrocatalytic Activities of $\mathrm{SnO}_{2}$ Electrodes for Remediation of Aqueous Pollutants by Doping with Various Metals. Applied Catalysis B: Environmental 2012, 111-112, 317-325.

20. Christensen, P. A.; Zakaria, K.; Curtis, T. P., Structure and Activity of Ni- and Sb-Doped $\mathrm{SnO}_{2}$ Ozone Anodes. Ozone: Science \& Engineering 2012, 34, 49-56.

21. Christensen, P. A.; Attidekou, P. S.; Egdell, R. G.; Maneelok, S.; Manning, D. A. C., An in Situ FTIR Spectroscopic and Thermogravimetric Analysis Study of the Dehydration and Dihydroxylation of $\mathrm{SnO}_{2}$ : The Contribution of the (100), (110) and (111) Facets. Physical Chemistry Chemical Physics 2016, 18, 22990-22998.

22. Fujihara, S.; Maeda, T.; Ohgi, H.; Hosono, E.; Imai, H.; Kim, S.-H., Hydrothermal Routes to Prepare Nanocrystalline Mesoporous $\mathrm{SnO}_{2}$ Having High Thermal Stability. Langmuir 2004, 20, 6476-6481.

23. Xue, Y.; Zhang, Y.; Zhang, P., Theory of the Color Change of $\mathrm{Na}_{\mathrm{x}} \mathrm{WO}_{3}$ as a Function of NaCharge Doping. Physical Review B 2009, 79, 205113.

24. Dusastre, V.; Williams, D. E., $\mathrm{Sb}(\mathrm{III})$ as a Surface Site for Water Adsorption on $\mathrm{Sn}(\mathrm{Sb}) \mathrm{O}_{2}$, and Its Effect on Catalytic Activity and Sensor Behavior. The Journal of Physical Chemistry $B$ 1998, 102, 6732-6737.

25. Rockenberger, J.; zum Felde, U.; Tischer, M.; Tröger, L.; Haase, M.; Weller, H., Near Edge X-Ray Absorption Fine Structure Measurements (XANES) and Extended X-Ray Absorption Fine Structure Measurements (EXAFS) of the Valence State and Coordination of Antimony in Doped Nanocrystalline $\mathrm{SnO}_{2}$ The Journal of Chemical Physics 2000, 112, 4296-4304.

26. Cross, Y. M.; Pyke, D. R., An X-Ray Photoelectron Spectroscopy Study of the Surface Composition of Tin and Antimony Mixed Metal Oxide Catalysts. Journal of Catalysis 1979, $58,61-67$. 
27. Egdell, R. G.; Cox, P. A.; Harding, C.; Patterson, W. R.; Tavener, P. J., Surface Properties of Antimony Doped Tin(IV) Oxide: A Study by Electron Spectroscopy. Surface Science 1982, 123, 179-203.

28. Ono, T.; Yamanaka, T.; Kubokawa, Y.; Komiyama, M., Structure and Catalytic Activity of $\mathrm{Sb}$ Oxide Highly Dispersed on $\mathrm{Sno}_{2}$ for Propene Oxidation. Journal of Catalysis 1988, 109, 423-432.

29. Slater, B.; Catlow, C. R. A.; Gay, D. H.; Williams, D. E.; Dusastre, V., Study of Surface Segregation of Antimony on $\mathrm{SnO}_{2}$ Surfaces by Computer Simulation Techniques. The Journal of Physical Chemistry B 1999, 103, 10644-10650.

30. McGinley, C.; Al Moussalami, S.; Riedler, M.; Pflughoefft, M.; Borchert, H.; Haase, M.; de Castro, A. R. B.; Weller, H.; Möller, T., Pure and Sb-Doped $\mathrm{Sno}_{2}$ Nanoparticles Studied by Photoelectron Spectroscopy. The European Physical Journal D - Atomic, Molecular, Optical and Plasma Physics 2001, 16, 225-228.

31. Sun, K.; Liu, J.; Browning, N. D., Correlated Atomic Resolution Microscopy and Spectroscopy Studies of $\mathrm{Sn}(\mathrm{Sb}) \mathrm{O}_{2}$ Nanophase Catalysts. Journal of Catalysis 2002, 205, 266-277.

32. Montilla, F.; Morallón, E.; De Battisti, A.; Barison, S.; Daolio, S.; Vázquez, J. L., Preparation and Characterization of Antimony-Doped Tin Dioxide Electrodes. 3. XPS and SIMS Characterization. The Journal of Physical Chemistry B 2004, 108, 15976-15981.

33. Egdell, R. G.; Flavell, W. R.; Tavener, P., Antimony-Doped Tin(IV) Oxide: Surface Composition and Electronic Structure. Journal of Solid State Chemistry 1984, 51, 345-354.

34. Grosvenor, A. P.; Biesinger, M. C.; Smart, R. S. C.; McIntyre, N. S., New Interpretations of XPS Spectra of Nickel Metal and Oxides. Surface Science 2006, 600, 1771-1779.

35. Nut, K., On the Dissolution Behavior of Nio. Corrosion Science 1970, 10, 571-583.

36. Pichugina, N. M.; Kutepov, A. M.; Gorichev, I. G.; Izotov, A. D.; Zaitsev, B. E., Dissolution Kinetics of Nickel(II) and Nickel(III) Oxides in Acid Media. Theoretical Foundations of Chemical Engineering 2002, 36, 485-494.

37. Pourbaix, M., Atlas of Electrochemical Equilibria in Aqueous Solutions; National Association of Corrosion Engineers: Houston, Tex., 1974, p 342.

38. D. D. Wagman, W. H. E., V. B. Parker, R. H. Schumm, I. Halow, S. M. Bailey, K. L. Churney, and R. L. Nuttall, The Nbs Tables of Chemical Thermodynamic Properties. Journal of Physical and Chemical Reference Data 1982, 11, 1807.

39. Bard, A. J.; Parsons, R.; Jordan, J., Standard Potentials in Aqueous Solution, 1st ed.. ed.; New York : M. Dekker: New York, 1985.

40. Freitas, R. G.; Antunes, E. P.; Christensen, P. A.; Pereira, E. C., The Influence of Ir and $\mathrm{Pt}_{1} \mathrm{Ir}_{1}$ Structure in Metallic Multilayers Nanoarchitectured Electrodes Towards Ethylene Glycol Electro-Oxidation. Journal of Power Sources 2012, 214, 351-357.

41. Harrison, P. G.; Guest, A., Tin Oxide Surfaces. Part 17.-an Infrared and Thermogravimetric Analysis of the Thermal Dehydration of Tin(IV) Oxide Gel. Journal of the Chemical Society, Faraday Transactions 1: Physical Chemistry in Condensed Phases 1987, 83, 3383-3397.

42. Morishige, K.; Kittaka, S.; Morimoto, T., The Thermal Desorption of Surface Hydroxyls on Tin(IV) Oxide. Bulletin of the Chemical Society of Japan 1980, 53, 2128-2132.

43. Morimoto, T.; Yokota, Y.; Kittaka, S., Adsorption Anomaly in the System Tin(IV) OxideWater. The Journal of Physical Chemistry 1978, 82, 1996-1999.

44. Morimoto, T.; Kiriki, M.; Kittaka, S.; Kadota, T.; Nagao, M., Differential Heat of Chemisorption. 3. Chemisorption of Water on Tin(IV) Oxide. The Journal of Physical Chemistry 1979, 83, 2768-2770.

45. Brown, I.; Patterson, W. R., Reactivity of Tin Oxide and Some Antimony-Tin Oxide Catalysts for the Oxidation of Methane and the Isotopic Exchange of Oxygen. An 
Examination of the Role of Adsorbed and Lattice Oxygen in Catalytic Oxidation. Journal of the Chemical Society, Faraday Transactions 1: Physical Chemistry in Condensed Phases 1983, 79, 1431-1449.

46. Mizusaki, J.; Koinuma, H.; Shimoyama, J.-I.; Kawasaki, M.; Fueki, K., High Temperature Gravimetric Study on Nonstoichiometry and Oxygen Adsorption of $\mathrm{SnO}_{2}$. Journal of Solid State Chemistry 1990, 88, 443-450.

47. Kotz, R.; Stucki, S.; Carcer, B., Electrochemical Waste Water Treatment Using High Overvoltage Anodes. Part I: Physical and Electrochemical Properties of $\mathrm{SnO}_{2}$ Anodes. Journal of Applied Electrochemistry 1991, 21, 14-20.

48. Montilla, F.; Morallón, E.; De Battisti, A.; Benedetti, A.; Yamashita, H.; Vázquez, J. L., Preparation and Characterization of Antimony-Doped Tin Dioxide Electrodes. Part 2. Xrd and Exafs Characterization. The Journal of Physical Chemistry B 2004, 108, 5044-5050.

49. Montilla, F.; Morallón, E.; De Battisti, A.; Vázquez, J. L., Preparation and Characterization of Antimony-Doped Tin Dioxide Electrodes. Part 1. Electrochemical Characterization. The Journal of Physical Chemistry B 2004, 108, 5036-5043.

50. Higgins, S.; Sammes, N. M.; Smirnova, A.; Kilner, J. A.; Tompsett, G., Yttrium-Doped Barium Zirconates as Ceramic Conductors in the Intermediate Temperature Range. Journal of Fuel Cell Science and Technology 2008, 5, 011003-011003.

51. Aldao, C. M.; Schipani, F.; Ponce, M. A.; Joanni, E.; Williams, F. J., Conductivity in $\mathrm{SnO}_{2}$ Polycrystalline Thick Film Gas Sensors: Tunneling Electron Transport and Oxygen Diffusion. Sensors and Actuators B: Chemical 2014, 193, 428-433.

52. Cathcart, J. V.; Perkins, R. A.; Bates, J. B.; Manley, L. C., Tritium Diffusion in Rutile $\left(\mathrm{TiO}_{2}\right)$. Journal of Applied Physics 1979, 50, 4110-4119.

53. Farver, J. R., Oxygen and Hydrogen Diffusion in Minerals. Reviews in Mineralogy and Geochemistry 2010, 72, 447-507.

54. Moore, D. K.; Cherniak, D. J.; Watson, E. B., Oxygen Diffusion in Rutile from 750 to $1000^{\circ} \mathrm{C}$ and 0.1 to $1000 \mathrm{Mpa}$. American Mineralogist 1998, 83, 700-711.

55. Scanlon, D. O.; Kehoe, A. B.; Watson, G. W.; Jones, M. O.; David, W. I. F.; Payne, D. J.; Egdell, R. G.; Edwards, P. P.; Walsh, A., Nature of the Band Gap and Origin of the Conductivity of $\mathrm{PbO}_{2}$ Revealed by Theory and Experiment. Physical Review Letters 2011, 107, 246402. 


\section{Figure captions}

1. Plots of ratio of grain volume (calculated from the BET surface areas) to crystallite volume (calculated from the XRD data using Scherrer's equation), for the $\mathrm{SnO}_{2}, \mathrm{Sb}_{-} \mathrm{SnO}_{2}$ and Ni/Sb$\mathrm{SnO}_{2}$ nanopowders calcined at (i) $400{ }^{\circ} \mathrm{C}$ and (ii) $700{ }^{\circ} \mathrm{C}$, see text for details. " $0.5 \% \mathrm{Ni}$ " is $0.5 \% \mathrm{Ni} / \mathrm{Sb}-\mathrm{SnO}_{2}$, fabricated from a precursor solution containing $0.5 \mathrm{wt} . \% \mathrm{Ni}$.

2. Plots of the rate of $\mathrm{O}_{3}$ evolution from $0.64 \mathrm{~cm}^{2}$ nanopowder and ceramic anodes vs the $\mathrm{Sb}$ (III) content obtained from the XPS data. The ozone evolution rate was determined after $30 \mathrm{~s}$ electrolysis of $0.5 \mathrm{M} \mathrm{H}_{2} \mathrm{SO}_{4}$ in a UV Vis cuvette cell at $2.7 \mathrm{~V}$ using a $0.64 \mathrm{~cm}^{2} \mathrm{Pt} / \mathrm{Ti}$ mesh cathode, see text for details

3. XPS spectra of the Ni2p region of (i) untested and 9ii) tested ceramic $1 \% \mathrm{Ni} / \mathrm{Sb}-\mathrm{SnO}_{2}$ anodes. See text for details.

4. The current density and ozone current efficiency observed during the durability testing of a ceramic $1 \% \mathrm{Ni} / \mathrm{Sb}-\mathrm{SnO}_{2}$ anode. The anode was employed to electrolyse $0.5 \mathrm{M} \mathrm{H}_{2} \mathrm{SO}_{4}$ twice a day for $30 \mathrm{~s}$, the electrolysis repeated three times for both electrolyses. Between electrolyses, the anode was left immersed in $0.5 \mathrm{M} \mathrm{H}_{2} \mathrm{SO}_{4}$ at open circuit.

5. (a) The thermogravimetric responses of the $\mathrm{SnO}_{2}$-containing nanopowders produced via the hydrothermal method and calcined at $400{ }^{\circ} \mathrm{C}$. The samples were heated in $40 \mathrm{~cm}^{3} \mathrm{~min}^{-1}$ flowing air at $5^{\circ} \mathrm{C} \mathrm{min}^{-1}$ from room temperature to $900{ }^{\circ} \mathrm{C}$. The samples were then held at $900^{\circ} \mathrm{C}$ for 10 minutes and then cooled at $5^{\circ} \mathrm{C} \mathrm{min}{ }^{-1}$ to room temperature. See Table ST5 for sample masses. (b) The differential plots of the curves in (a).

6. Plots of the mass of water released during heating up to $150{ }^{\circ} \mathrm{C}$ in TGA experiments conducted using all nanopowder samples calcined at $400{ }^{\circ} \mathrm{C}$ vs the surface area of the particles calculated from the crystallite sizes using the Scherrer equation and assuming spherical crystallites.

7. Plots of water coverage at $25^{\circ} \mathrm{C}$ on the Sb-containing nanoparticles calcined at (i) $400{ }^{\circ} \mathrm{C}$ and (ii) $700{ }^{\circ} \mathrm{C}$ calculated from TGA and XRD data vs the $\mathrm{Sb}$ (III) content of the samples, determined using XPS.

8. Plots of water coverage at $25^{\circ} \mathrm{C}$ on the Sb-containing nanoparticles as a function of $\mathrm{Sb}$ (III) content.

9. (a) The thermogravimetric response of $56.0 \mathrm{mg}$ of the $\mathrm{SnO}_{2}$ nanopowder produced via the hydrothermal method and calcined at $400{ }^{\circ} \mathrm{C}$. The sample was heated in $40 \mathrm{~cm}^{3} \mathrm{~min}^{-1}$ flowing air at $5^{\circ} \mathrm{C} \mathrm{min}{ }^{-1}$ from room temperature to $900{ }^{\circ} \mathrm{C}$. The sample was held at $900^{\circ} \mathrm{C}$ for 10 minutes and then cooled at $5^{\circ} \mathrm{C} \mathrm{min}^{-1}$ to room temperature. This cycle was repeated a further three times. (i) Cycle 1, (ii) cycle 2 and (iii) cycle 4. (b) The thermogravimetric responses of the $\mathrm{SnO}_{2}$-containing nanopowders produced via the hydrothermal method and calcined at $400{ }^{\circ} \mathrm{C}$. The samples were heated in $40 \mathrm{~cm}^{3} \mathrm{~min}^{-1}$ flowing air at $5^{\circ} \mathrm{C} \mathrm{min}{ }^{-1}$ from room temperature to $900{ }^{\circ} \mathrm{C}$. The samples were held at $900^{\circ} \mathrm{C}$ for 10 minutes and then cooled at $5^{\circ} \mathrm{C} \mathrm{min}{ }^{-1}$ to room temperature. This cycle was repeated a further three times. Only the fourth cycles are shown. See Table ST6 for sample masses.

10. The differential mass plots of the heating parts of the TGA responses in fig. 9(b).

11. A plot of the number of $\mathrm{O}_{2}$ molecules gained per $\mathrm{Sn}$ atom for all the $\mathrm{Sb}-\mathrm{SnO} \mathrm{O}_{2}$ and $\mathrm{Ni} / \mathrm{Sb}-\mathrm{SnO} \mathrm{O}_{2}$ nanopowders calcined at $400{ }^{\circ} \mathrm{C}$ vs the $\mathrm{Sb}$ (III) content, from the TGA data on the heating part of the $4^{\text {th }}$ cycles up to ca. $350^{\circ} \mathrm{C}$, the BET surface areas of the samples and XPS data. See Table ST6 for sample masses.

12. (a) Plots of current efficiency vs Ni content of the $700{ }^{\circ} \mathrm{C} \mathrm{Sb}-\mathrm{SnO}_{2} / \mathrm{Ni} \mathrm{T}_{2}$ samples with $\mathrm{T}_{2}=$ $460{ }^{\circ} \mathrm{C}$ and $700{ }^{\circ} \mathrm{C}$. (b) Plots of current density vs Ni content for the samples in fig. 12(a).

13. Conceptual model of the grains and crystallites of the $\mathrm{Ni} / \mathrm{Sb}-\mathrm{SnO}_{2}$ nanopowders. 


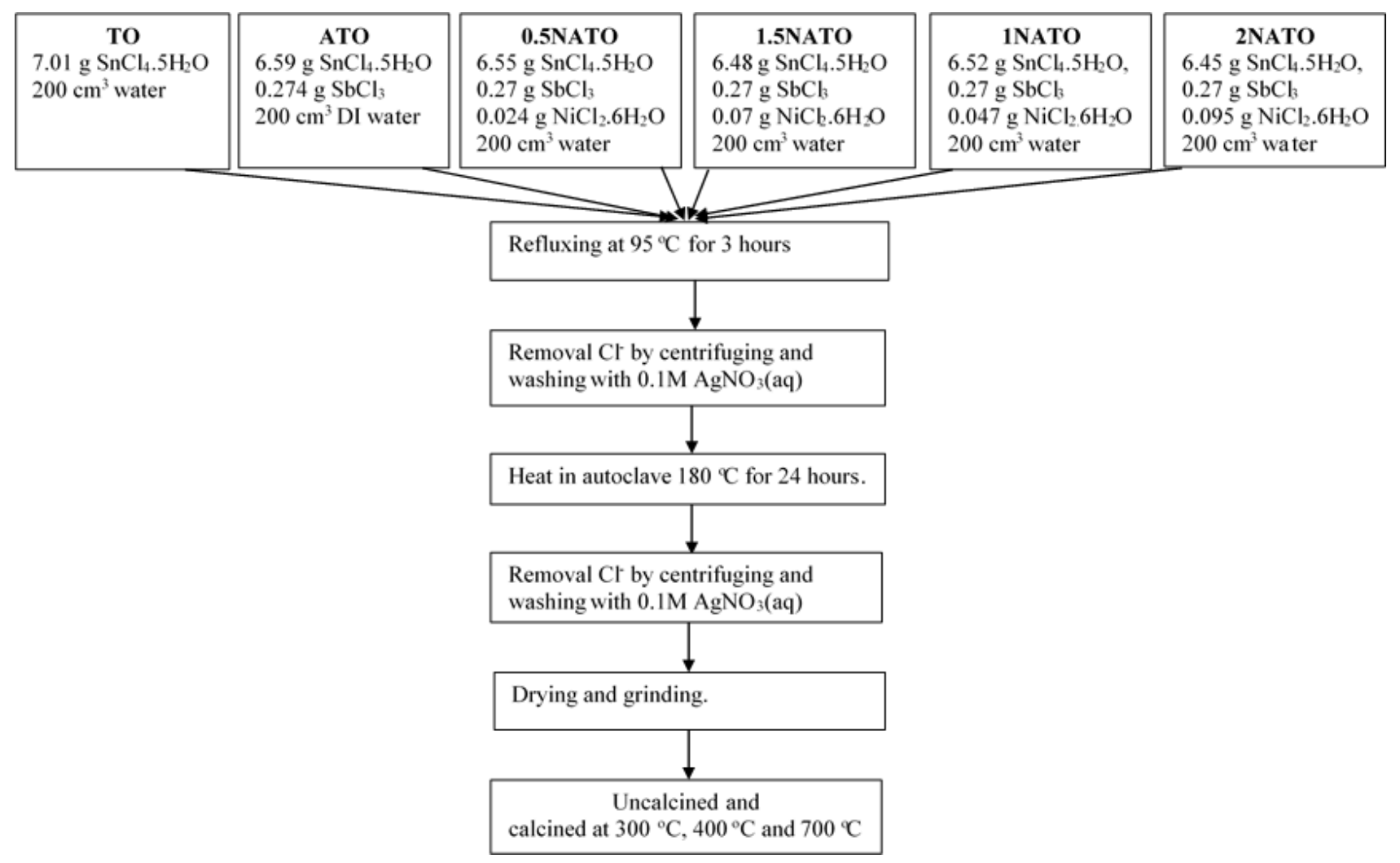

Scheme 1. The preparation of the $\mathrm{SnO}_{2}, \mathrm{Sb}-\mathrm{SnO}_{2}$ and $\mathrm{Ni} / \mathrm{Sb}-\mathrm{SnO}_{2}$ nanpowders. 


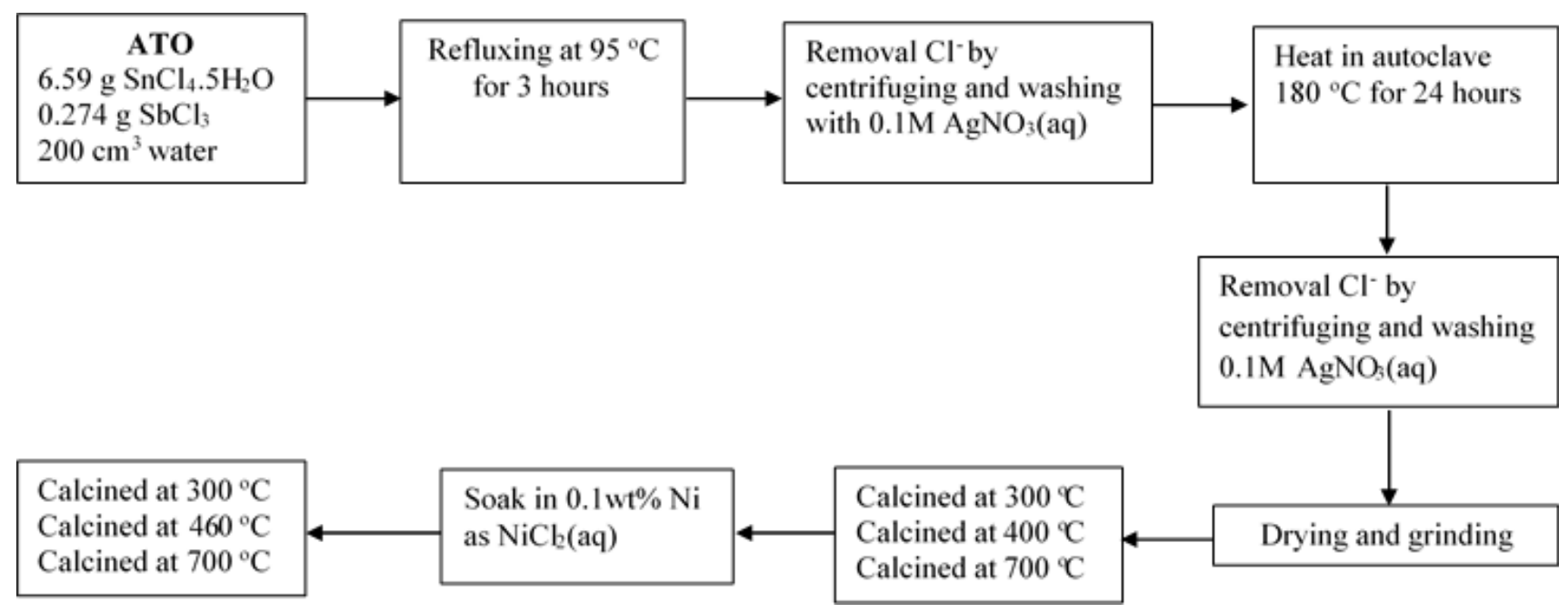

Scheme 2. The preparation of the $\mathrm{Sb}-\mathrm{SnO}_{2} / \mathrm{Ni}$ nanopowders. 


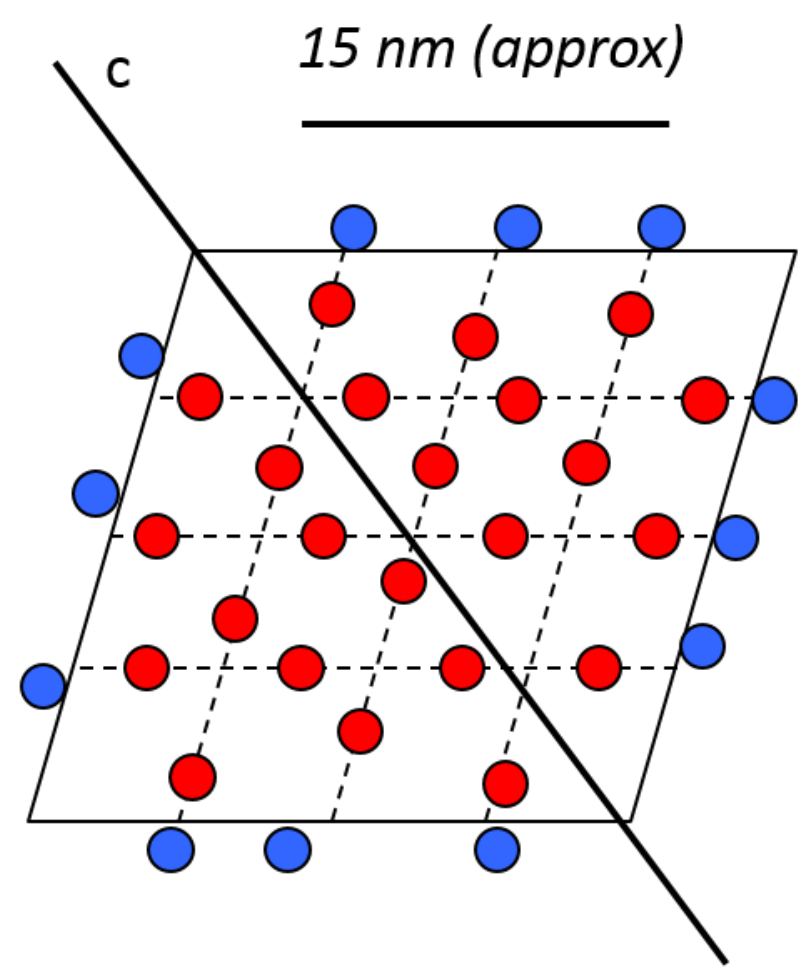

--.--- Crystallite surfaces (XRD)

- Particle surfaces (BET)

$\bigcirc \quad \mathrm{O}_{3}$

$\bigcirc \mathrm{OH}$

TOC graphic 